\title{
Spontaneous recovery from uncomplicated acute appendicitis
}

\author{
Samoistne wyleczenie w niepowikłanym zapaleniu wyrostka robaczkowego
}

Department of Paediatric Surgery and Urology, The Independent Public Clinical Hospital No. 6 of the Medical University of Silesia in Katowice, John Paul II Upper Silesian Child Health Centre, Katowice, Poland Correspondence: Szymon Tobor, Piastowska 7, 41-922 Radzionków, Poland, tel.: +48 785319 475, e-mail: szymon.tobor@wp.pl

\begin{abstract}
Background: Historically, acute appendicitis requires surgical treatment. In recent years, there has been an increased interest in treating uncomplicated cases in a conservative way. The development in radiological and laboratory diagnosis has allowed for better possibilities of identification and watchful waiting of simple appendicitis. Objectives: The aim of the study was a retrospective evaluation of the efficacy of conservative treatment of uncomplicated acute appendicitis in children diagnosed based on clinical, laboratory and sonographic signs. Materials and methods: The diagnosis of uncomplicated acute appendicitis was based on the clinical signs, laboratory tests and ultrasound findings. Two clinical criteria, one laboratory criterion and two sonographic criteria, were assumed as a clear diagnosis of appendicitis. the retrospective assessment was conducted among 382 children who were hospitalised for suspected appendicitis. In those we identified a group of 66 children who met the criteria of acute appendicitis. The efficacy of conservative treatment in patients who met the criteria mentioned above was evaluated. Results: Within the period of at least one year, $89.4 \%$ of patients (59/66) were not re-hospitalised for recurrent symptoms. Eventually, $92.4 \%$ of patients (61/66) included in the study did not require surgical treatment. Conclusion: Uncomplicated acute appendicitis should be initially treated conservatively with watchful waiting. The vast majority of uncomplicated appendicitis cases can resolve spontaneously.
\end{abstract}

Keywords: abdominal pain, acute appendicitis, uncomplicated appendicitis, conservative treatment

Wstęp: Historycznie ukształtowaną metodą leczenia ostrego zapalenia wyrostka robaczkowego jest leczenie chirurgiczne. W ostatnich latach wzrosło zainteresowanie terapią zachowawczą przypadków niepowikłanych. Dzięki rozwojowi badań radiologicznych i laboratoryjnych istnieją lepsze możliwości identyfikacji i aktywnej obserwacji prostego zapalenia wyrostka robaczkowego. Cel: Celem pracy jest retrospektywna ocena skuteczności leczenia zachowawczego niepowikłanego ostrego zapalenia wyrostka robaczkowego u dzieci, u których ustalono rozpoznanie na podstawie objawów klinicznych, badań laboratoryjnych i ultrasonograficznych. Materiał i metody: Diagnozę nieskomplikowanego ostrego zapalenia wyrostka robaczkowego oparto na objawach klinicznych, wynikach badań laboratoryjnych i ultrasonograficznych. Jako jednoznaczne rozpoznanie zapalenia wyrostka robaczkowego przyjęto spełnienie co najmniej dwóch kryteriów klinicznych, jednego kryterium laboratoryjnego oraz dwóch kryteriów ultrasonograficznych. Ocenę retrospektywną przeprowadzono wśród 382 dzieci hospitalizowanych z powodu podejrzenia zapalenia wyrostka robaczkowego. W tej grupie zidentyfikowano grupę 66 dzieci, które spełniały kryteria ostrego zapalenia wyrostka robaczkowego. Skuteczność postępowania zachowawczego oceniono u pacjentów, którzy spełniali wyżej wymienione kryteria. Wyniki: W okresie co najmniej roku 89,4\% pacjentów (59/66) nie wymagało ponownej hospitalizacji z powodu nawrotu objawów zapalenia wyrostka robaczkowego. Ostatecznie u 92,4\% pacjentów (61/66) objętych badaniem nie było konieczności wdrożenia leczenia chirurgicznego. Wniosek: Niepowikłane ostre zapalenie wyrostka robaczkowego należy początkowo leczyć zachowawczo, wykorzystując aktywną obserwację. Zdecydowana większość przypadków niepowikłanego zapalenia wyrostka robaczkowego może ustępować samoistnie.

Słowa kluczowe: ból brzucha, ostre zapalenie wyrostka robaczkowego, niepowikłane zapalenie wyrostka robaczkowego, leczenie zachowawcze 


\section{BACKGROUND}

S urgical removal of the appendix has long been the only therapeutic option in cases of appendicitis. Appendectomy alone or with concomitant antibiotics leads to almost complete limitation of related mortality. However, in recent years conservative treatment has emerged as an alternative option in cases of uncomplicated acute appendicitis ${ }^{(1-4)}$. Controversies of nonoperative therapy concern several issues: the efficacy and the risk of the treatment as well as clear diagnosis, which can be confirmed by histology of the removed appendix. Despite the existing clinical scoring systems (ALVARADO score for acute appendicitis ${ }^{(5)}$ or Pediatric Appendicitis Score - PAS ${ }^{(6)}$ ), which do not include ultrasonographic signs, the preoperative diagnosis of appendicitis remains uncertain.

The aim of the study was an evaluation of the efficacy of conservative treatment of uncomplicated acute appendicitis in children in whom the diagnosis was retrospectively stated based on clinical, laboratory and sonographic signs.

\section{MATERIALS AND METHODS}

Appendicitis was diagnosed based on clinical signs, as well as laboratory and ultrasound (US) findings. Clinical signs included tenderness in the right lower quadrant, rebound pain, muscular defence in the right lower quadrant, elevated temperature $\left(>37.2^{\circ} \mathrm{C}\right)$, vomiting or nausea, anorexia. Abnormal laboratory findings included elevated C-reactive protein $(\mathrm{CRP})(>10 \mathrm{mg} / \mathrm{L})$ and high white blood cell (WBC) count ( $<6$ years WBC $>15.5 \mathrm{G} / \mathrm{L}, 6-12$ years $\mathrm{WBC}>13.5 \mathrm{G} / \mathrm{L}$ and $>12$ years $\mathrm{WBC}>10 \mathrm{G} / \mathrm{L})$. US signs were large diameter of the appendix $(>6 \mathrm{~mm})$, thick appendicular wall $(>2 \mathrm{~mm})$, pain in the appendicular area due to US probe pressure, periappendiceal infiltration, increased blood flow in the appendicular wall in colour Doppler and rigidity of the appendicular wall. Meeting at least two clinical criteria, one laboratory criterion and two sonographic criteria was assumed as a clear diagnosis of appendicitis.

The available data of all children admitted to our institution between 2011 and 2016 due to abdominal pain were analysed retrospectively. Among 382 children referred due to suspected appendicitis and eventually not qualified for surgical treatment, we identified a group of 66 children who met the assumptive criteria of acute appendicitis. Mean patient age was 11.7 years (4-17 years). There were 35 girls and 31 boys. The patients were initially disqualified from surgical intervention by one of eight supervising paediatric surgeons with at least 20 years of professional experience. According to the Bioethical Committee, no formal ethical approval for this retrospective study was necessary (Letter no.

\begin{tabular}{|l|c|c|c|c|c|}
\hline \multirow{2}{*}{\begin{tabular}{l} 
Clinical criteria \\
\cline { 2 - 5 }
\end{tabular}} & \multicolumn{3}{|c|}{ Number of criteria met } & \multirow{2}{*}{$\begin{array}{c}\text { Total } \\
\text { number } \\
\text { of patients } \\
\text { for a given } \\
\text { criterion }\end{array}$} \\
\hline $\begin{array}{l}\text { Right iliac fossa } \\
\text { tenderness } \\
\text { on palpation }\end{array}$ & 39 & 19 & 3 & 1 & 62 \\
\hline Peritoneal signs & 7 & 4 & 2 & 1 & 14 \\
\hline Muscular defence & 4 & 7 & 2 & 1 & 14 \\
\hline $\begin{array}{l}\text { Body temperature } \\
\geq 37.2^{\circ} \mathrm{C}\end{array}$ & 10 & 13 & 1 & 1 & 25 \\
\hline Vomiting & 18 & 10 & 3 & 1 & 32 \\
\hline Nausea & 5 & 6 & - & - & 11 \\
\hline Lack of appetite & 1 & 1 & 1 & - & 3 \\
\hline $\begin{array}{l}\text { Number of patients } \\
\text { who met a particular } \\
\text { number of criteria }\end{array}$ & 42 & 20 & 3 & 1 & 66 \\
\hline
\end{tabular}

Tab. 1. Collation of patients together with clinical criteria

\begin{tabular}{|c|c|c|}
\hline Elevated inflammatory indicators & \multicolumn{2}{|c|}{ Number of patients } \\
\hline CRP & $27 / 66$ & $40.9 \%$ \\
\hline WBC & $23 / 66$ & $34.8 \%$ \\
\hline$C R P+W B C$ & $13 / 66$ & $19.7 \%$ \\
\hline
\end{tabular}

Tab. 2. Collation of patients together with inflammatory indicators

\begin{tabular}{|c|c|c|}
\hline Indicator & Onset & Follow-up \\
\hline WBC [G/L] & 17.5 & 10 \\
\hline CRP $[\mathrm{mg} / \mathrm{l}]$ & 42.6 & 33.7 \\
\hline CRP - C-reactive protein; WBC - white blood cells. \\
\hline
\end{tabular}

Tab. 3. Mean inflammatory indicators

\section{RESULTS}

The mean duration of abdominal pain in children prior to admission to our institution was 1.28 days (range $0-7$ days). The majority of children $(42 / 66=63.6 \%)$ met two clinical criteria of appendicitis, 20 children (30.3\%) met three criteria and 4 children met more than three criteria (Tab. 1). Tenderness in right lower quadrant was the most common clinical sign (93.9\%).

At admission, both CRP and WBC levels were high in 13 children (19.7\%); high CRP and normal WBC values were found in 27 children (40.9\%); high WBC and normal CRP values were found in 23 children $(34.8 \%)$ (Tab. 2). In 3 children (4.6\%), both inflammatory markers were normal at admission, but elevated CRP level was reported during the hospitalisation (mean $16.1 \mathrm{mg} / \mathrm{L}$ ). Generally, high CRP was the most common laboratory abnormality. Mean CRP serum level at admission was $42.6 \mathrm{mg} / \mathrm{L}$ (range $10.1-175.0 \mathrm{mg} / \mathrm{L}$ ) in 40 children. In several cases, it was higher in control tests, but eventually returned to normal values. Mean WBC count on admission was 17.5 G/L (range 10.1-29.1 G/L) in 36 children and it normalised within a few days (Tab. 3). 


\begin{tabular}{|c|c|c|c|c|c|}
\hline \multirow[b]{2}{*}{$\begin{array}{l}\text { Sonographic } \\
\text { criteria }\end{array}$} & \multicolumn{4}{|c|}{ Number of criteria met } & \multirow{2}{*}{$\begin{array}{c}\text { Total } \\
\text { number } \\
\text { of patients } \\
\text { for a given } \\
\text { criterion }\end{array}$} \\
\hline & 2 & 3 & 4 & 5 & \\
\hline Diameter $>6 \mathrm{~mm}$ & 20 & 18 & 6 & 3 & 47 \\
\hline $\begin{array}{l}\text { Thickness of the wall } \\
>2 \mathrm{~mm}\end{array}$ & 8 & 6 & 2 & 3 & 19 \\
\hline $\begin{array}{l}\text { Pain in the area of } \\
\text { the appendix due to } \\
\text { the ultrasonography } \\
\text { probe pressure }\end{array}$ & 6 & 6 & - & 2 & 14 \\
\hline $\begin{array}{l}\text { Periappendiceal } \\
\text { infiltration }\end{array}$ & 11 & 20 & 8 & 3 & 42 \\
\hline $\begin{array}{l}\text { Increased blood flow } \\
\text { in the appendiceal } \\
\text { wall on Color Doppler } \\
\text { examination }\end{array}$ & 6 & 2 & 8 & 1 & 17 \\
\hline $\begin{array}{l}\text { Rigidity of the } \\
\text { appendix to the } \\
\text { ultrasonography } \\
\text { probe pressure }\end{array}$ & 11 & 20 & 8 & 3 & 42 \\
\hline $\begin{array}{l}\text { Number of patients } \\
\text { who met a particular } \\
\text { number of criteria }\end{array}$ & $\begin{array}{c}31 \\
(46.9 \%)\end{array}$ & $\begin{array}{c}24 \\
(36.4 \%)\end{array}$ & $\begin{array}{c}8 \\
(12.1 \%)\end{array}$ & $\begin{array}{c}3 \\
(4.6 \%)\end{array}$ & $\begin{array}{c}66 \\
(100 \%)\end{array}$ \\
\hline
\end{tabular}

Tab. 4. Collation of patients together with ultrasonographic criteria

At least two US diagnostic signs of appendicitis were found in all patients at admission (Tab. 4). The most common US parameter was enlarged diameter of the appendix $>6 \mathrm{~mm}(68.2 \%)$ followed by rigidity of the appendicular wall (62.1\%) and periappendiceal infiltration (56.1\%). The mean values of widening and thickening of the appendiceal wall were $0.94 \mathrm{~cm}$ (range $0.65-1.87 \mathrm{~cm}$ ) and $0.45 \mathrm{~cm}$ (range $0.25-1.10$ ), respectively. No signs of perforation or other complications in US parameters were found in follow-up examination.

Intravenous fluid with no oral intake was applied in all affected patients for at least 24 hours since the admission until the clinical condition improved. If clinical condition improved, oral fluids were permitted and, if well tolerated, "light" diet and successively regular diet was introduced. Antibiotics were not routinely used. However, 8 children (12\%) received intravenous amoxicillin/clavulanic acid due to concomitant infection of the respiratory tract.

The patients were discharged home after 1-8 days in good general condition, without clinical symptoms, with reduced CRP and WBC values and without deterioration of US parameters.

One child (girl) was readmitted to hospital after three days and underwent appendectomy. Within successive 8-16 months, appendectomy had to be performed in 4 other patients. Two more patients were readmitted due to abdominal pain; however, nonsurgical management was again efficient. The remaining 59 children (89.4\%) did not develop abdominal pain within the follow-up period of at least one year. In total, 61 children (92.4\%) did not require appendectomy despite diagnosis of appendicitis.

\section{DISCUSSION}

Recent advances in medicine have contributed not only to the treatment process but also, importantly, to the diagnosis itself. Surgical regulations for qualification in acute diseases of the abdominal cavity remain valid. For many decades, appendectomy has been considered as a treatment of choice in acute appendicitis. It has eliminated historically fatal course of untreated appendicitis. The diagnosis was typically based only on clinical signs and symptoms. Therefore, many unnecessary appendectomies have been performed $^{(7,8)}$. The complication rate of surgery is as high as $8.2 \%$ for open procedure and $7.2 \%$ for laparoscopic one, with possible complications including organ puncture, intestinal damage, vascular damage, bleeding and wound rupture $^{(9)}$. For this reason, the viewpoint on diagnostic criteria for appendicitis is changing, including US into them may influence the way of qualifying patients for either surgical or conservative treatment.

High quality US has improved the imaging of the appendix. It has high sensitivity, specificity and positive predictive value $^{(1)}$. Ultrasonography combined with elements of clinical scoring systems (ALVARADO or PAS) ensures a more accurate diagnosis of appendicitis. It applies also to children in whom the symptoms diminish or even resolve spontaneously ${ }^{(1,10)}$. Therefore, in our opinion, many children were disqualified from surgical treatment based on repeated clinical evaluation although they actually suffered from appendicitis. US also helps distinguish between uncomplicated and complicated cases ${ }^{(11)}$. Complicated appendicitis includes perforation of the appendix, abscess formation, generalised peritonitis, and sepsis. Unquestionably, appendectomy (open or laparoscopic) still remains the treatment of choice in such cases ${ }^{(12,13)}$.

Conservative therapy of uncomplicated appendicitis based on antibiotics has been widely analysed in many studies $^{(1,10,14,15)}$. Various antibiotic regimens have been proposed, e.g. intravenous (IV) ampicillin/sulbactam or piperacillin/ tazobactam for 5-7 days; IV ceftriaxone/metronidazole for 3-5 days, followed by oral amoxicillin/clavulanic acid for next 5 days; IV cefotaxime for at least 3 days; IV amoxicillin/clavulanic acid etc. ${ }^{(1,2,10,14,15)}$. The outcomes of antibiotic treatment are similar as far as the safety and management efficacy are concerned ${ }^{(3,4,15)}$. According to several authors, $14-21 \%$ of conservatively treated children had to be re-admitted to hospital; however, only about $8.6-12 \%$ of them required surgical treatment ${ }^{(1,3)}$.

However, clinical and epidemiological studies of the natural course of acute appendicitis suggest that it tends to resolve spontaneously ${ }^{(16)}$. Although effective conservative treatment of the inflammatory process with the use of antibiotic therapy is not surprising, the results of studies indicating effective treatment of appendicitis without antibiotics may come as a surprise ${ }^{(17)}$. There is also some literature evidence that there are no differences between conservative treatment with or without antibiotics. Furthermore, the authors of this 
paper indicated that there is no increased risk of perforation among the groups treated without antibiotics ${ }^{(18)}$.

On the other hand, surgical treatment eliminates recurrence of the appendicitis and therefore is often preferred by surgeons and even by the affected patients ${ }^{(19)}$. However, conservative treatment should be especially considered in children who do not present with clinical signs of complications and those with spinal injury in whom the appendix can be necessary for creation of catheterisable vesicostomy (Mitrofanoff) or MACE procedure ${ }^{(20,21)}$.

Considering the results of our study as well as data from current literature, conservative treatment may be recommended as the first choice option in children with uncomplicated appendicitis.

\section{CONCLUSION}

The vast majority of uncomplicated appendicitis cases can resolve spontaneously. Therefore, watchful waiting alone can be an alternative option that should be considered whilst making the decision and informing the parents.

\section{Conflict of interest}

The authors do not declare any financial or personal links with other persons or organisations that might adversely affect the content of the publication or claim any right to the publication.

\section{References}

1. Caruso AM, Pane A, Garau R et al.: Acute appendicitis in children: not only surgical treatment. J Pediatr Surg 2017; 52: 444-448.

2. Steiner Z, Buklan G, Stackievicz R et al.: Conservative treatment in uncomplicated acute appendicitis: reassessment of practice safety. Eur J Pediatr 2017; 176: 521-527.

3. Tanaka $Y$, Uchida $\mathrm{H}$, Kawashima $\mathrm{H}$ et al.: Long-term outcomes of operative versus nonoperative treatment for uncomplicated appendicitis. J Pediatr Surg 2015; 50: 1893-1897.

4. Georgiou R, Eaton S, Stanton MP et al.: Efficacy and safety of nonoperative treatment for acute appendicitis: a meta-analysis. Pediatrics 2017; 139: e20163003.

5. Ohle R, O'Reilly F, O'Brien KK et al.: The Alvarado score for predicting acute appendicitis: a systematic review. BMC Med 2011; 9: 139.
6. Samuel M: Pediatric Appendicitis Score. J Pediatr Surg 2002; 37 : 877-881.

7. Emil S, Laberge JM, Mikhail P et al.: Appendicitis in children: a ten-year update of therapeutic recommendations. J Pediatr Surg 2003; 38: 236-242.

8. Hale DA, Jaques DP, Molloy M et al.: Appendectomy. Improving care through quality improvement. Arch Surg 1997; 132: 153-157.

9. Andersson RE: Short-term complications and long-term morbidity of laparoscopic and open appendicectomy in a national cohort. Br J Surg 2014; 101: 1135-1142.

10. Jimbo K, Takeda $\mathrm{M}$, Miyata $\mathrm{E}$ et al.: Is a pediatrician performed gray scale ultrasonography with power Doppler study safe and effective for triaging acute non-perforated appendicitis for conservative management? J Pediatr Surg 2016; 51: 1952-1956.

11. Gonzalez DO, Lawrence AE, Cooper JN et al.: Can ultrasound reliably identify complicated appendicitis in children? J Surg Res 2018; 229: 76-81.

12. Elmore JR, Dibbins AW, Curci MR: The treatment of complicated appendicitis in children. What is the gold standard? Arch Surg 1987; 122: 424-427.

13. Klempa I: [Current therapy of complicated appendicitis]. Chirurg 2002; 73: 799-804.

14. Steiner Z, Buklan G, Stackievicz R et al.: A role for conservative antibiotic treatment in early appendicitis in children. J Pediatr Surg 2015; 50: 1566-1568.

15. Di Saverio S, Sibilio A, Giorgini E et al.: The NOTA Study (Non Operative Treatment for Acute Appendicitis): prospective study on the efficacy and safety of antibiotics (amoxicillin and clavulanic acid) for treating patients with right lower quadrant abdominal pain and long-term follow-up of conservatively treated suspected appendicitis. Ann Surg 2014; 260: 109-117.

16. Andersson RE: The natural history and traditional management of appendicitis revisited: spontaneous resolution and predominance of prehospital perforations imply that a correct diagnosis is more important than an early diagnosis. World J Surg 2007; 31: $86-92$.

17. Ohba G, Hirobe S, Komori K: The usefulness of combined $\mathrm{B}$ mode and Doppler ultrasonography to guide treatment of appendicitis. Eur J Pediatr Surg 2016; 26: 533-536.

18. Park HC, Kim MJ, Lee BH: Randomized clinical trial of antibiotic therapy for uncomplicated appendicitis. Br J Surg 2017; 104: 1785-1790.

19. Hanson AL, Crosby RD, Basson MD: Patient preferences for surgery or antibiotics for the treatment of acute appendicitis. JAMA Surg 2018; 153: 471-478.

20. Mitrofanoff $P$ : [Trans-appendicular continent cystostomy in the management of the neurogenic bladder]. Chir Pediatr 1980; 21: 297-305.

21. Malone PS, Ransley PG, Kiely EM: Preliminary report: the antegrade continence enema. Lancet 1990; 336: 1217-1218. 